Slagjana JAKIMOVIK, Ph.D.

УДК 37.016:51-028.31

Faculty of Pedagogy "St. Kliment Ohridski"

-оригинални научни рад-

"Ss Cyril and Methodius" University in Skopje

Macedonia

\title{
THE MATHEMATICS EDUCATION OF PRE-SCHOOL TEACHERS
}

\begin{abstract}
The foundation for children's mathematical development is established in the early childhood through experiences which challenge infants and preschoolers to explore ideas related to patterns, shapes, numbers and space. These early experiences influence significantly children's disposition for mathematics, hence they need to be positive and supportive. The ability of pre-school teachers to provide young learners with such experiences requires both profound understanding of fundamental mathematical ideas and positive attitude toward mathematics. Analysis of the results on the entry test administered to first year students, prospective pre-school teachers, at the Faculty of Pedagogy "St. Kliment Ohridski" in Skopje, at the beginning of the semester during five consecutive academic years (2006/07-2010/11) show extremely low levels of initial mathematics competencies of the majority of the students. These results together with research studies in this field establish the need for a high-quality mathematics education to be provided for prospective pre-school teachers within their university studies. The question of what kind of mathematics education is required to equip future pre-school teachers with the competencies to promote young learners' development of mathematical abilities is addressed through theoretical considerations of research studies of mathematics education in early childhood.
\end{abstract}

Key words: mathematics education, pre-school teachers, mathematics competencies, entry test.

\section{Introduction}

How do people learn mathematics? When does this process start? What enhances the development of mathematics competencies, and what hinders it? Are all people capable of acquiring basic mathematical competencies or is mathematics really for the few "math gifted" individuals? The answers to these and to many more questions regarding the learning of mathematics significantly influence educational policy, in general, and mathematics curriculum development, in particular.

According to Resnick (1989), there is a broad agreement among various research groups including cognitive, developmental, and educational psychologist as well as mathematics educators, on how people learn mathematics: mathematical knowledge is not simply absorbed but it is constructed 
by each individual, and this process starts well before formal education starts. Intuitive understanding of many mathematical concepts begins to form during the years from birth through pre-school. Humans are born with the capacity to understand fundamental mathematical ideas - mathematics is not a figment of someone's imagination or unrelated to everyday practices of people.

Bruner introduced the paradigmatic mode and syntagmatic mode of cognitive functioning, "each providing distinctive ways of ordering experience, of constructing reality" (1986, p.11). Syntagmatic thinking is based on tacit knowledge and acquired as part of everyday communication in the family and in everyday live, as opposed to paradigmatic thinking which deals in general cases, uses procedures in testing for empirical truth, and consistency and non-contradiction are required (Kleve, 2011). Paradigmatic mode "employs categorization or conceptualization and the operations by which categories are established, instantiated, idealized, and related to one another in a system" (Bruner, 1986, p.12). Kleve (2011) explains that for mathematics, procedural knowledge takes place in a syntagmatic mode of thinking, and conceptual knowledge takes place in a paradigmatic mode of thinking. Only competent teachers can lead children successfully through the process of transition from syntagmatic to paradigmatic mode of thinking since children learn to form new mathematical concepts on which they can perform operations while interacting with their teachers who are capable of using the concepts in a paradigmatic mode.

In referral to the 1999 report of the Carnegie Corporation, the authors of the Principles and Standards for School Mathematics (2000, p.74) emphasize that "Children's long-term success in learning and development requires high quality experiences during the 'years of promise'." According to the Principles and Standards for School Mathematics (2000, p.73):

Mathematics at this age, if appropriately connected to a child's world, is more than 'getting ready' for school or accelerating them into elementary mathematics. Appropriate mathematical experiences challenge young children to explore ideas related to patterns, shapes, numbers and space with increasing sophistication.

Similarly to elementary school teachers, pre-school teachers need to approach mathematical activities in the classroom equipped with understanding and knowledge of mathematics, as well as with awareness of the salient issues that emerge in the mathematical classroom regarded as a mathematics laboratory for young learners' mathematical explorations. Neither only the skillful use of appropriate didactical methods and tools, nor only the knowledge of the cognitive levels of children they work with, are sufficient to imbue teachers with confidence in their own competencies for teaching mathematics to pre-school children. "Seeing the mathematics in the world that surrounds them" is determined firstly by teachers' deep understanding of core mathema- 
tical ideas. Lack of such understanding prevents teachers to use the richness of mathematical examples that appear in children's everyday life and limits them to a few textbook examples. It leads to a failure to "foster children's mathematical development by providing environments rich in language, where thinking is encouraged, uniqueness is valued, and exploration is supported" as emphasized in Principles and Standards for School Mathematics (2000, p.74). Teachers who do not trust their own abilities to make sense of mathematics induce the same mistrust in their students from very young age. As justly noted in Principles and Standards for School Mathematics (2000, p.74):

Because young children develop a disposition for mathematics from their early experiences, opportunities for learning should be positive and supportive; children must learn to trust their own abilities to make sense of mathematics.

It is of major importance for university studies to provide prospective pre-school teachers with sufficient mathematical and didactical background to be able to support children's cognitive growth and acquisition of essential mathematical competencies.

In order to properly address this question of importance, two questions which immediately arise are:

1. What kind of mathematical knowledge and skills prospective preschool teachers bring to their university studies?

2. What kind of mathematical knowledge and skills do pre-school teachers need in order to promote the development of mathematical competencies of young learners in their charge?

An attempt to address each of the questions, the first one empirically, the second one theoretically, is presented in the paper without the pretence of giving a complete answer.

\section{Mathematics background of first year students of Pre-school teacher education studies}

Whether mathematics courses should be offered to prospective preschool teachers is an issue which has received different treatment in various teacher training faculties in the Republic of Macedonia with either no courses offered at all or a one semester course being compulsory in the first year of studies. Students enrolled at the pre-school teacher studies have various background with respect to the mathematics courses they took in their previous schooling. The results from the entry test administered to first year students, prospective pre-school teachers, in the first week of the semester in which a mathematics course is offered open certain questions which cannot be disregarded if the aim is to establish solid grounds for further high quality mathematics education for all students at all levels of education. 
The diagnostic test consisted of 14 open-ended items covering various areas of elementary mathematics. A description of each of the items is given in the Appendix, along with the number of points assigned to each problem (given in brackets).

The test was administered to first year students, prospective preschool teachers, in Macedonian and in Turkish language of instruction. The number of students who took the test each academic year is given in Table 1 .

Table 1. Sample size each academic year

\begin{tabular}{||l|c|c|c|c|c||}
\hline \multicolumn{1}{|c|}{ Academic year } & $\begin{array}{c}2006 / \\
2007\end{array}$ & $\begin{array}{c}2007 / \\
2008\end{array}$ & $\begin{array}{c}2008 / \\
2009\end{array}$ & $\begin{array}{c}2009 / \\
2010\end{array}$ & $\begin{array}{c}2010 / \\
2011\end{array}$ \\
\hline $\begin{array}{l}\text { Number of students } \\
\text { who took the course }\end{array}$ & 109 & 126 & 84 & 74 & 43 \\
\hline $\begin{array}{l}\text { Number of students } \\
\text { who took the diagnostic test }\end{array}$ & 59 & 60 & 35 & 32 & 19 \\
\hline $\begin{array}{l}\text { Percent of students } \\
\text { who took the diagnostic test }\end{array}$ & $54,13 \%$ & $47,62 \%$ & $41,67 \%$ & $43,24 \%$ & $44,19 \%$ \\
\hline
\end{tabular}

The number of students who took the test appears to be low in comparison to the number of students who took the course partly because part time students did not take the test. Students' lack of motivation to take the test as it carries less than $5 \%$ to the total points assigned to the course also contributes to the small percent of students who took the test.

\section{The results from the entry test}

The results from the diagnostic entry test by academic year are given in Diagram 2. The results show extremely low mathematics competencies of first year students, prospective pre-school teachers. The percent of students who earned 0 points on each question in 2006/07 is more than alarming: almost $46 \%$. The following years these percents were lower: $20 \%$ in $2007 / 08$, almost $23 \%$ in 2008/09, slightly more than $28 \%$ in $2009 / 10$, and slightly more than $5 \%$ in $2010 / 11$. These numbers indicate the numbers of students each year that failed even to describe or sketch a square, a rectangle, a triangle, a circle or a cube! Out of 50 points assigned to the test, the maximal number of points received by a student ranges from 17 points in $2008 / 09$ and in 2010/11, around 25 points in $2006 / 07$ and $2007 / 08$, to 30 points in 2009/10, reached by only one or two students the respective year. 


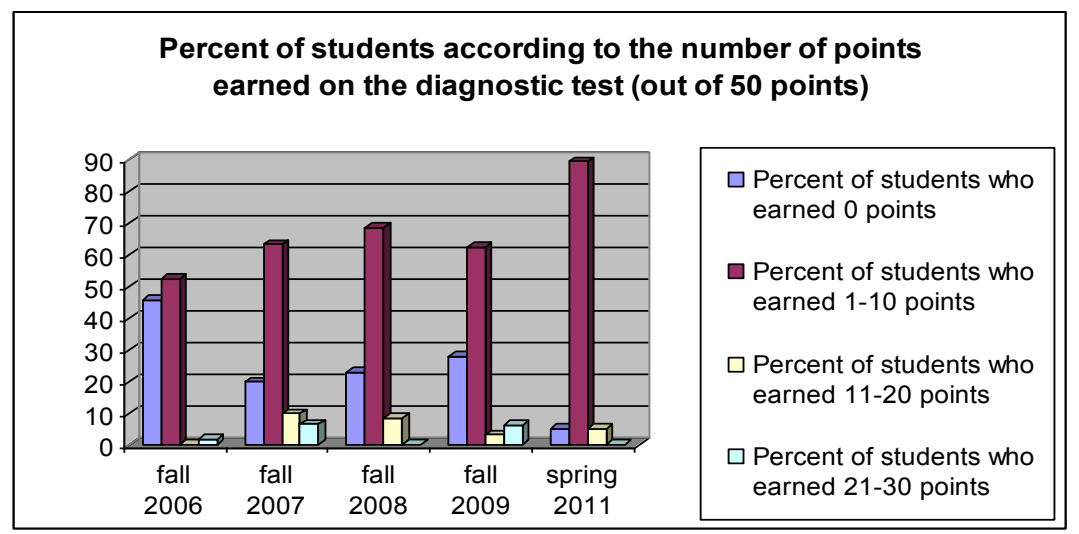

Diagram 2. The results from the diagnostic test by academic year

In general, students showed lack of procedural fluency when facing fractional and decimal arithmetic. Although learned in the first three grades of elementary school, representation of sets by Venn diagrams and determination of the intersection and the union of two or of three sets proved to be an obstacle for more than $60 \%$ to $80 \%$ of the students each year. Roman numerals seem to be forgotten by all but 3 of all the students who took the test from 2006/07 to 2010/11. A few of all of the students (only 8 students) recognized the proportional problem as such, and even fewer of them solved it correctly. GCD and LCF did not ring a bell for all but couple of students each year except in 2007/08.

Students' failure to describe or sketch a basic geometric shape as a square, a rectangle, a rectangular triangle, a circle, or a solid as a cube, a cuboid, a ball, a cylinder, a cone or a pyramid is probably the most concerning fact that emerged from the results on the diagnostic test. The majority of above mentioned shapes and solids are meant to be introduced to 6-7 year old pupils by their pre-school or elementary school teachers! Failure to find the perimeter or the area of a rectangle points toward the problem of students not understanding basic ideas of geometry and measurement used constantly in everyday life. A very small number of the students' papers contained application of Pythagoras's theorem when solving a rectangular triangle. Overall, geometry appears to be an even weaker point of students' previous mathematics education than arithmetic.

Entry test administered to first year students, prospective elementary school teachers, during four consecutive academic years (2006/07-2009/10) showed similar results (Jakimovik 2011; Јакимовиќ \& Тимовски, 2011). Although Јакимовиќ and Тимовски (2011) offer a list of possible related factors, the reasons behind the low levels of mathematics competencies that students have acquired during their previous schooling are complex and require an in depth investigation of current teaching practices in primary and secondary schools in the Republic of Macedonia, as well as a study of current mathematics curriculum objectives and textbooks in use. 


\section{Mathematical knowledge for teaching pre-school mathematics}

Although the entry test shed some light on certain aspects of first year students' mathematical background, among which their procedural fluency and their problem solving skills, it could not reveal the whole picture as it was not designed to do so. Students' beliefs regarding the nature of mathematics, of mathematics learning and of mathematics teaching were not investigated. Yet, it is worth considering the approach taken by Schmidt et al. (2007), as cited by Delaney (2012), regarding school mathematics teachers' professional competencies. In addition to teachers' professional knowledge which includes mathematics content knowledge and didactics of mathematics knowledge, a significant component of teachers' professional competencies represent teachers' professional beliefs, consisting of beliefs regarding the epistemology of mathematics, instructionally related beliefs regarding the learning of mathematics and instructionally related beliefs about the teaching of mathematics.

Mathematics content knowledge required for teaching mathematics in primary schools, referred to as mathematical knowledge for teaching (MKT), is an extensively researched domain (for overviews see, for example, Ball, Lubienski \& Mewborn, 2001; Blömeke \& Delaney, 2012; Jakimovik, 2013). Although much has been done regarding the conceptualization of the domain of MKT, according to the National Mathematics Advisory Panel, existing research on aspects of teacher education is not of sufficient rigor or quality to allow for general conclusions to be made about the features of professional training that have effects on teachers' knowledge, their instructional practice, or their students' achievements (NMAP, 2008). In comparison, research efforts on mapping the domain of pre-school teachers mathematical knowledge are quite rare and of limited scope, mainly focused on investigations of the young learners' development of mathematics competencies and more or less restricted to case studies of individual children.

A case study from a Norwegian kindergarten analyzing and discussing the differences between the tasks of teaching observed in this kindergarten setting and the tasks of teaching in a school setting, relates to the MKT framework (Mosvold et al., 2011). Their findings suggest that the MKT model of the proposed tasks of teaching (Ball et al, 2008), although applicable, has to be modified. Specifically, they propose "to merge the tasks of 'presenting mathematical ideas' to pupils in schools and the task of 'finding an example to make a specific mathematical point' into 'facilitating and using activities and play situations that enable children to experience mathematical ideas"” (Mosvold et al., 2011, p.9-10). They also suggest adapting the task of 'connecting a topic being taught to topics from prior or future years' to reflect the essence of the challenge a Norwegian kindergarten teacher faces in "uncovering and building upon the children's previous informal knowledge and experiences from everyday activities and play situ- 
ations" (Mosvold et al., 2011, p.10) due to the fact that early childhood education in the Nordic countries has the characteristics of the social pedagogy tradition. Actually, one may argue that the same recommendations hold even within the early childhood education in the pre-primary tradition, where nationally adopted documents define the pre-school curriculum.

A section of the conferences of the European Society for Research in Mathematics Education, known as the Working group on Early Years Mathematics, deals with the research domain of mathematics learning and mathematics education in the early years, age 3 to 7 . Only a few studies explicitly report on investigations of pre-school teachers' mathematics education or on the mathematical requirements of pre-school teachers' profession. Yet, implications from the results of research studies on children's development of mathematical ideas and concepts may be analysed with the aim to discern the mathematical requirements of the pre-school teachers' job.

On the basis of an empirical research study (rooted in the methodological framework of Grounded Theory) on the relationship of young children playing and learning mathematics, Schuler (2011) concluded that the organization of "early mathematics education in informal contexts like free play with potentially suitable materials and games" is based on "a mathematical, didactical, pedagogical and conversational competence" which has to be part of the qualifications of pre-school teachers. This kind of studies proposes the need for the investigation of the domain of mathematical knowledge of pre-school teachers.

Several studies in different countries in Europe on 6-year old pupils' mathematical competencies at the beginning of first grade revealed the gross underestimation that both school teachers and researchers showed when asked to estimate those competencies (see, for example, Jakimovik et al., 2013). The low cognitive levels of the goals defined in the nationally adopted mathematics curriculum for early grades do not lend much support to pre-school teachers in designing meaningful learning opportunities for their young students. These findings add more emphasis to the need for university education of pre-school teachers to address these issues, both in mathematical and didactical terms.

A study which explores the ability of kindergarteners' (age 4-6) to take half of an increasing number of discrete items and the strategies they employ in doing so, in addition to providing a deeper understanding of children's conception of half, produced the added benefit of understanding "the importance of implementing a variety of tasks when trying to assess children's knowledge as well as requesting children, even young children, to explain their actions" (Tirosh et al., 2011, p.9). Although these findings cannot be generalized due to the characteristics of the sample, they present indicators of what pre-school teachers' mathematical work with young learners entails. 
Supporting and nurturing the development of non symbolic forms of algebraic thinking in young children is a relevant research question in mathematics education in early childhood (Malone, 2011). The appearance of algebraic thinking is not a necessary consequence of cognitive maturation; it requires certain pedagogical settings (Radford, 2010). Seeing the mathematically productive qualities of activities, games and questions which lead young learners to explore mathematical ideas and possibly to employ natural strategies like "looking for tricks" (Malone, 2011), requires competent and knowledgeable adults, the kindergarten teachers.

Aaten et al. (2011) reported results on kindergarten age (5-6 years old) children's imaginary perspective taking abilities with respect to determining whether an object is visible from a different viewpoint, and with respect to determining the appearance of an object from a different point of view. They found that the first kind of competence precedes the second, and that both competencies increase significantly from the age of 5 through the age of 6 , which signifies a major development of spatial visualization abilities within one year. They also found that "the children's mathematics performance level is significantly related to their imaginary perspective taking competencies" (Aaten et al., 2011, p.8). These findings indicate the need for pre-school teachers' awareness of how these kinds of abilities develop, but they also require pre-school teachers to be able to develop and enact mathematical activities which will support the development of these competences. What kind of mathematical knowledge and understanding is required on behalf of the teachers is yet to be investigated.

Kindergarten teachers increased their awareness in "what mathematics may look like in the kindergarten environment and in unfolding mathematical activities in the kindergarten" within a developmental research project which enabled kindergarten teachers and university researchers to engage in co-learning experiences (Hundeland et al., 2011). Fostering long term collaboration within inquiry communities among researchers and kindergarten teachers is significant in more than one ways. One of them is the emergence of increased understanding of the mathematics entailed in everyday work of kindergarten teachers.

\section{Conclusions}

Mathematical knowledge and skills that prospective pre-school teachers bring to their university programs are of very low levels, well below the curricular goals of school mathematics. Particularly concerning are students deficiencies in elementary arithmetic and basic algebra, as well as basic geometry and measurement. 
University education of prospective pre-school teachers needs to address this problem within an appropriate mathematics course. Motivating students to engage in serious efforts to develop their mathematics competencies seems to be one of the major steps to be made in this direction. The way to achieve this is to model a course closely related to students' real life experiences and their own expectations for their future profession: what kind of knowledge would they need to meet the cognitive needs of pre-school children.

A meaningful design of a university mathematics course for prospective pre-school teachers may be attempted only on the basis of a good understanding of what kind of mathematics knowledge is entailed in preschool teachers' everyday work with young learners. Further research in this domain is required. Establishing long term collaboration in co-learning communities of practicing kindergarten teachers, mathematics educators and didacticians of mathematics has the potential to be the most productive way of achieving this goal. Equipping future pre-school teachers with competencies for engaging in reflective practices and for adopting the role of attentive observers of their young students' emerging mathematical ideas is the most useful vehicle for enabling teachers to become active promoters of the development of the mathematical thinking of children.

\section{References}

1. Aaten, A. B., van den Heuvel-Panhuizen, M., \& Elia, I. (2011). Kindergartners' perspective taking abilities. CERME 7. Retrieved on 22.1.2011, from http:// www.cerme7.univ.rzeszow.pl/WG/13/CERME7 WG13 Aaten.pdf.

2. Ball, D. L., Thames, M. H., \& Phelps, G. (2008). Content knowledge for teaching: What makes it special? Journal of Teacher Education, 59(5), 389-407.

3. Ball, D. L., Lubienski, S., \& Mewborn, D. (2001). Research on teaching mathematics: The unsolved problem of teachers' mathematical knowledge. In V. Richardson (Ed.), Handbook of research on teaching ( $4^{\text {th }} e d$.), MacMillan, New York, 433-456.

4. Blömeke, S., \& Delaney, S. (2012). Assessment of teacher knowledge across counties: A review of the state of research. ZDM 44(3), 223-247.

5. Bruner, J. (1986). Actual Minds, Possible Words. Cambridge, London: Harvard University Press.

6. Delaney, S. (2012). A validation study of the use of mathematical knowledge for teaching measures in Ireland. ZDM 44(3), 427-441.

7. Hundeland, P. S., Carlsen, M., \& Erfjord, I. (2011). Changing mathematical practice of kindergarten teachers. Co-learning in a developmental research project, CERME 7. Retrieved from http://www.cerme7.univ.rzeszow.pl/WG/13/ CERME7_WG13_Hundeland.pdf, on 22.1.2011.

8. Jakimovik, S. (2011). Initial problem-solving competencies of the first year students, prospective elementary school teachers, at the Pedagogical faculty in Skopje (2006/07-2009/10), IMO, Vol. III (2011), Broj 5, pp. 5-12 (electronic) 
9. Jakimovik, S. (2013). Measures of mathematical knowledge for teaching and university mathematics courses design. In V. Kiryakova (Ed.) "Complex Analysis and Applications'13" (Proc. Intern. Conf., Sofia, 2013), Institute of Mathematics and Informatics, Bulgarian Academy of Sciences, 118-138.

10. Јакимовиќ, С., Тимовски, В. (2011), Почетните математички компетенции на студентите од прва година на Педагошкиот факултет во Скопје, Teacher in the Balkan Cultures (International scientific Conference, Vranje, December 2010), University of Niš, Teacher-training faculty in Vranje, 125-142.

11. Jakimovik, S., Trajanovska, I., Gogovska, V., \& Atanasova-Pachemska, T. (2013). What mathematics school beginners know and can do - a matter of importance or not? Croatian Journal of Education, 15 Sp. Ed. No. 1, 99-110.

12. Kleve, B. (2011). Literacy in mathematics - a challenge for teachers in their work with pupils, CERME 7. Retrieved from http://www.cerme7.univ. rzeszow. pl/WG/17a/CERME7_WG17A_Kleve.pdf, on 22.1.2011.

13. Malone, M. (2011). "Looking for tricks": A natural strategy, early forerunner of algebraic thinking, Cerme 7. Retrieved from http://www.cerme7.univ.rzeszow. pl/WG/13/CERME7 WG13 Malone.pdf, on 22.1.2011.

14. Mosvold, R., Bjuland, R., Fasukanger, J., \& Jakobsen, A. (2011). Similar but different - Investigating the use of MKT in a Norwegian kindergarten setting, CERME 7. Retrieved from http://www.cerme7.univ.rzeszow.pl/WG/13/CERME7 WG13 Mosvold.pdf, on 22.1.2011.

15. National Council of Teachers of Mathematics (2000). Principles and Standards for School Mathematics. Reston, Va.: National Council of Teachers of Mathematics.

16. National Mathematics Advisory Panel (2008). Foundations for Success: The Final Report of the National Mathematics Advisory Panel, U.S. Department of Education, Washington, DC.

17. Schuler, S. (2011). Playing and learning in early mathematics education - Modelling a complex relationship, CERME 7. Retrieved on 22.1.2011, from http:// www.cerme7.univ.rzeszow.pl/WG/13/CERME7 WG13 Schuler.pdf.

18. Radford, L. (2010). Elementary form of algebraic thinking in young students. In Pinto, M. F. \& Kawasaki, T. F. (Eds.). Proceedings of the $34^{\text {th }}$ Conf. of the Int. Group for the Psychology of Mathematics Education, Vol. 4, 73-80, Belo Horizonte, Brazil: PME.

19. Resnick, L.B. (1989). Developing Mathematical Knowledge. American Psychologist, 44, 162-169. Retrieved from http://www.lrdc.pitt.edu/publications/pdfs/ 200905061105570.developingmath.pdf.

20. Schmidt, W. H., Tatto, M. T., Bankov, K., Blömeke, S., Cedillo, T., Cogan, 1., ... Schwille, J. (2007). The preparation gap: Teacher education for middle school mathematics in six countries (MT21 Report). East Lansing, MI: Center for Research in Mathematics and Science Education, Michigan State University.

21. Tirosh, D., Tsamir, P., Tabach, M., Levenson, E., \& Barkai, R. (2011). Can you take a half? Kindergarten children's responses. CERME 7. Retrieved on 22.1.2011, from http://www.cerme7.univ.rzeszow.pl/WG/13/CERME7 WG13 Tirosh.pdf. 


\section{Appendix}

1. Arithmetic operations with fractions (4 pts).

2. Arithmetic operations with decimal numbers (4 pts).

3. Knowledge and proper use of symbols $\subseteq, \in, \cap, \cup$ in appropriate contexts (2 pts).

4. Representation of sets with Venn diagrams and set operations (intersection, union, difference) (4 pts).

5. Representing and reading numbers with Roman numerals (2pts).

6. Solving a context problem which involves a proportion (2pts).

7. Finding the greatest common factor of two numbers $(1 \mathrm{pt})$.

8. Finding the least common multiple of two numbers $(1 \mathrm{pt})$.

9. Description of a geometric shape (a polygon, a square or a rectangle) and a solid (a cube or a cuboid), and sketching those (4pts).

10. Length, area and volume units of measure conversion (3pts).

11. Sketching and calculating the perimeter and the area of geometric shapes (a. a rectangle, and b. a rectangular triangle) ( 3 pts and 5 pts respectively)

12. Solving simple linear inequality with one unknown and interval representation of the solution ( $3 \mathrm{pts}$ ).

13. Sketching and calculating the circumference and the area of a circle or calculating the area and the volume of a ball (3 pts).

14. Sketching and calculating the area and the volume of a pyramid or a cone (9 pts).

Проф. др Слађана Јакимовић

\section{МАТЕМАТИЧКО ЗНАЮЕ ВАСПИТАЧА}

Сажетак: Основа математичког напретка код деце поставља се у раном детињству кроз искуства која представљају изазов за врло малу деиу и деиу предиколског узраста да истражују појмове везане за обрасие, облике, бројеве и простор. Ова рана искуства значајно утичу на дечју диспозииију за математику, стога она требају бити позитивна и пружити деции подрику. Способност васпитача да младим ученищима обезбеде таква искуства захтева темељно разумевање основних математичких појмова и позитиван став према математици. Анализа резултата пријемног теста обављеног са студентима прве године, потениијалним васпитачима, на Педагошком факултету „Св. Климент Охридски“ “ С Скопљу, почетком семестра током пет узастопних школских година (2006/2007-2010/2011) показује изузетно низак

Примљено: 16. 11. 2013. године.

Одобрено за штампу: 28. 11. 2013. године. 
ниво иницијалних математичких компетенција код већине студената. Ови резултати, заједно са истраживањима у овој области, намећу потребу за обезбеђивањем високо квалитетног образовања из области математике за будуће васпитаче у оквиру њиховог програма студирања. Питање о томе каква је врста образована из области математике неопходна да би будући васпитачи стекли компетениије за унапређење развоја математичких способности код младих ученика обрађено је кроз теоријска разматраға истраживачких проучавања математичког образовања у раном детињству.

Кључне речи: математичко образовање, васпитачи, математичке компетенције, пријемни тест. 